\title{
ELEMENTAL CONCENTRATIONS AND SOIL-TO-MOSS TRANSFER FACTORS OF RADIONUCLIDES IN THE ENVIRONMENT OF NORTH KOSOVO AND METOHIJA
}

\author{
LJILJANA GULAN ${ }^{*}$, TATJANA JAKŠIĆ ${ }^{1}$, BILJANA MILENKOVIĆ2 JELENA STAJIĆ $^{2}$ \\ ${ }^{1}$ Faculty of Sciences, University in Priština - Kosovska Mitrovica, Kosovska Mitrovica, Serbia \\ ${ }^{2}$ University of Kragujevac, Institute for Information Technologies, Kragujevac, Department of Science, Kragujevac, \\ Serbia
}

\begin{abstract}
This paper deals with investigations of elemental concentrations and soil-to-moss transfer factors of radionuclides in area of municipalities Kosovska Mitrovica and Zubin Potok. Twelve samples of soil and moss Hypnum cupressiforme $\mathrm{Hedw}$. were collected during May 2018. Transfer factors of radionuclides: ${ }^{226} \mathrm{Ra},{ }^{232} \mathrm{Th},{ }^{40} \mathrm{Kand}{ }^{137} \mathrm{Cs}$ were calculated with regard to elemental concentrations of radionuclides in soil and moss samples. Analysis was done in order to indicate the different ways of adopting radionuclides by mosses. According to calculated transfer factors and analysis, authors concluded that the soil is dominant source of natural radionuclides and their concentration in moss occurred due to resuspension of soil particles, while artificial ${ }^{137}$ Cs is present in soil and moss samples as a consequence of atmospheric dry and wet deposition.
\end{abstract}

Keywords: Elemental concentration, Transfer factor, Radionuclide, Moss, Soil.

\section{INTRODUCTION}

Primordial radionuclides ${ }^{226} \mathrm{Ra},{ }^{232} \mathrm{Th}$ and ${ }^{40} \mathrm{~K}$ are present in all soils and rocks. They are permanent source of irradiation of all biological species in nature, since they have long half-lives. Different chemical forms of these naturally occurring radionuclides emit gamma radiation which is known as terrestrial background. Therewith natural background radiation includes cosmic radiation and radon inhalation.

Besides natural radioactivity, the environment is uneven contaminated with artificial radionuclides, among them the radiologically most important is ${ }^{137} \mathrm{Cs}$ (half-life 30.07 y). It occurred in significant amounts particularly after the Chernobyl accident, as well as a consequence of nuclear tests and accidents after II World War. Therefore, exposure to any type of radiation poses some risk (UNSCEAR, 2008).

Radionuclides are incorporated in biological systems through the food chain, because plants rather absorb nutrients from soil than foliar (from particles suspended in air, transported by wind and precipitated by rainfall). On the other hand, the biological species that have ability to accumulate trace elements could serve as bio-indicators of radioecological status of an area.

Mosses are suitable for monitoring the ambient changes in the environment, since they have widespread geographical distribution and "evergreen phase" during the year. They also have high surface in comparison to volume and slowly grow with little morphological changes during the lifespan (Aceto et al., 2003; Ivanić et al., 2019; Fernandez \& Carballeira, 2000).

Mosses are sensitive to climatic variations, which affect their growing, physiological activity, uptake and retention of

*Coresponding author: 1jiljana.gulan@pr.ac.rs elements (Zechmeister et al., 2008; Dolegowska \& Migaszewski, 2019). Bioaccumulation of trace elements in moss tissue depends on: the atmospheric concentrations and uptake of contaminants, precipitation, elevation, vegetation cover and topography of the sampling site.

Recently, radionuclides in soils and mosses have been investigated in regions of Serbia by many authors (Mitrović et al., 2009; Dragović \& Mihailović, 2009; Grdović et al., 2010; Dragović et al., 2010; Čučulović et al., 2012; Mitrović et al., 2016; Krmar et al., 2018).

This is the first environmental study which used mosses as indicators of radiological contamination in area of Kosovska Mitrovica and Zubin Potok municipalities, North Kosovo and Metohija. The aims of this work were to determine elemental concentrations of radionuclides $\left({ }^{226} \mathrm{Ra},{ }^{232} \mathrm{Th}\right.$ and $\left.{ }^{40} \mathrm{~K}\right)$ and concentrations of radioactive ${ }^{137} \mathrm{Cs}$ from atmospheric fallout in soil and moss samples, as well to calculated transfer factors in order to discuss various adopting ways of radionuclides.

\section{MATERIALS AND METHODS}

Study area

This study deals with the investigation of elemental concentration of radionuclides in soil and moss samples in the area of municipalities Kosovska Mitrovica and Zubin Potok (Figure 1). Twelve sampling sites of hilly terrain, in the slopes of surrounding mountains (Mokra Gora, Rogozna and Kopaonik) were marked (S1-S12) on the Figure 1.

The relief is characterized by a diverse geological structure with rocks of different origin and age (granite, serpentinite, shale, marble, andesite, limestone). 
The mainly sedimentary, but magmatic and metamorphic rocks consist of shales, gabbro amphibolite, andesites and quartz latites. The part of relief was undergone the karst process in the carbonate rocks with the tectonic movements, which caused numerous fissures and cracks (Dimitrijević, 1997).

The study area belongs to moderately continental climate with cold winter and moderately warm summers. The edges of mountains and valleys between 1000 and 1500 meters of height have sub-mountainous climate (Ivanović et al., 2016). An average amount of precipitation is more than $700 \mathrm{~mm}$ and increased with altitude. The measured precipitation in the nearest town Kosovska Mitrovica (510 m a.s 1.) was $657.6 \mathrm{~mm}$ and $535.7 \mathrm{~mm}$ during 2017 and 2018, respectively (Hydrometeorological Yearbook of Kosovo, 2017-2018).

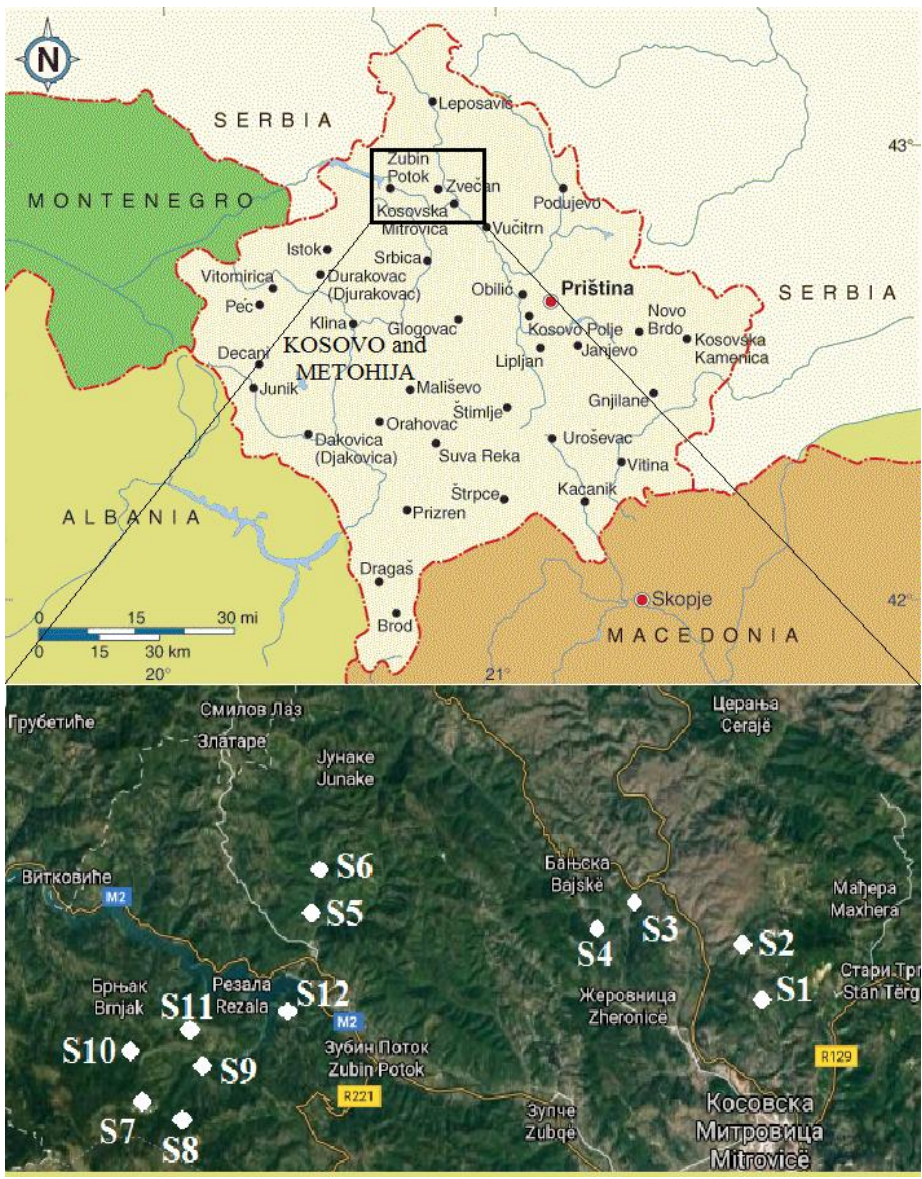

Figure1. Map of the study area.

\section{Sample collection and preparation}

Moss samples of Hypnum cupressiforme Hedw. and soil samples were collected from 12 locations (Figure 1). Sampling was performed in open areas away from trees, and far from towns, single houses and motorways during May 2018. Four samples of moss and soil from area of Kosovska Mitrovica, and eight ones from Zubin Potok were collected.

Hypnum cupressiforme Hedw. (Hypnaceae) is a group of mosses species with a wide variety of habitats in different climatic zones. It has irregularly branched shoots (older parts are brown color, and younger are green) covered with strongly curved leaves; the stem leaves are concave and sickle-shaped. Capsules with spores are located on the top of the stems. They are rootless, and usually grow 3-5 years on tree trunks, rocks, ground and other surfaces (Frahm, 2009).

The collected moss samples were of carpet-forming growth types. A compound sample was made from five to ten subsamples collected and mixed in within the same site. Samples were stored in paper bags. After transporting to the laboratory, they have been cleaned from litter and dead leaves. Only green and greenish-brown parts of the moss were used for gamma spectrometric analysis. These moss parts represent 3-5 years of plant growth. Underlying soil samples $(0-10 \mathrm{~cm})$ were also collected, cleaned from stones and roots, dried to constant weight, pulverized and sieved. All samples were packed in Marinelli beakers (450 mL), sealed, and left aside for a month to ensure equilibrium between ${ }^{226} \mathrm{Ra}$ and its progeny.

\section{Gamma spectrometry}

Gamma spectrometric measurements of soil and moss samples were performed with coaxial HPGe detector (GEM3070 ORTEC) of $30 \%$ relative efficiency and $1.65 \mathrm{keV}$ FWHM at $1.33 \mathrm{MeV}\left({ }^{60} \mathrm{Co}\right)$ and $717 \mathrm{eV}$ at $122 \mathrm{keV}\left({ }^{57} \mathrm{Co}\right)$. Detector was shielded with $10 \mathrm{~cm}$ of lead to reduce the background.

Specific activities of ${ }^{226} \mathrm{Ra},{ }^{232} \mathrm{Th},{ }^{40} \mathrm{~K}$ and ${ }^{137} \mathrm{Cs}$ in soil and moss samples were measured for $21600 \mathrm{~s}$ and $172800 \mathrm{~s}$, respectively. System calibration was done with standard mixture MBSS 2 of gamma-emitting isotopes $\left({ }^{241} \mathrm{Am},{ }^{109} \mathrm{Cd},{ }^{139} \mathrm{Ce},{ }^{57} \mathrm{Co}\right.$, ${ }^{60} \mathrm{Co},{ }^{137} \mathrm{Cs},{ }^{113} \mathrm{Sn},{ }^{85} \mathrm{Sr},{ }^{88} \mathrm{Y},{ }^{203} \mathrm{Hg},{ }^{152} \mathrm{Eu}$ ) provided by the Czech Metrology Institute. Maestro 32 was used for peak readings. The intensities and gamma lines of considering radionuclides are presented in Table 1.

Table 1. Intensities and gamma lines of radionuclides.

\begin{tabular}{|c|c|c|c|}
\hline Radionuclide & Progeny & $\begin{array}{c}\text { Gamma energy } \\
(\mathrm{keV})\end{array}$ & Intensity (\%) \\
\hline${ }^{226} \mathrm{Ra}$ & ${ }^{214} \mathrm{~Pb}$ & 351.9 & 37.1 \\
& ${ }^{214} \mathrm{Bi}$ & 609.3 & 46.1 \\
& ${ }^{214} \mathrm{Bi}$ & 1764.5 & 15.9 \\
\hline${ }^{232} \mathrm{Th}$ & ${ }^{228} \mathrm{Ac}$ & 338.3 & 12 \\
& ${ }^{228} \mathrm{Ac}$ & 911.1 & 29 \\
& ${ }^{228} \mathrm{Ac}$ & 968.9 & 17.5 \\
& ${ }^{208} \mathrm{Tl}$ & 583.0 & 86 \\
& ${ }^{208} \mathrm{Tl}$ & 860.6 & 12 \\
\hline${ }^{40} \mathrm{~K}$ & & 1460.7 & 10.7 \\
\hline${ }^{137} \mathrm{Cs}$ & & 661.6 & 84.6 \\
\hline
\end{tabular}

The total uncertainty of the activity measurements which includes the uncertainty of calibration source activity, efficiency of calibration and counting statistical errors were in the range of $3-10 \%$ 


\section{Elemental concentrations of radionuclides}

Elemental concentrations of ${ }^{226} \mathrm{Ra},{ }^{232} \mathrm{Th}$ and ${ }^{40} \mathrm{~K}$ were obtained by converting their specific activities according the following equation (Tzortzis \& Tsertos, 2004; Dragović et al., 2006):

$$
F_{E}=\frac{M_{E} C}{\lambda_{E, i} N_{A} f_{E, i}} A_{E}
$$

where $F_{E}$ is the fraction of element $\mathrm{E}$ in the sample, $M_{E}, \lambda_{E, i}, f_{E, i}$ and $A_{E, i}$ are the atomic mass $(\mathrm{kg} / \mathrm{mol})$, the decay constant of the measured isotope $i$ of the element $\mathrm{E}(1 / \mathrm{s})$, the fractional atomic abundance in nature and measured specific activity of the element $\mathrm{E}(\mathrm{Bq} / \mathrm{kg})$, respectively, $N_{A}$ is the Avogadro's number $\left(6.023 \cdot 10^{23} 1 / \mathrm{mol}\right)$, and $C$ is a constant with a value of $10^{6}$ for radium/thorium, and $10^{2}$ for potassium. Hence, elemental concentrations $F_{E}$ are reported in units of ppm (equivalent to $\mathrm{mg} / \mathrm{kg}$ ) for ${ }^{226} \mathrm{Ra}$ and ${ }^{232} \mathrm{Th}$, and as a percentage $(\%)$ for ${ }^{40} \mathrm{~K}$. Thus, if it is assumed that in uranium series radioactive equilibrium exists, then the concentrations of ${ }^{226} \mathrm{Ra},{ }^{232} \mathrm{Th}$ and ${ }^{40} \mathrm{~K}$ can be calculated using the conversion factors:

$$
\begin{aligned}
& 1 \mathrm{~Bq} / \mathrm{kg} \text { of }{ }^{226} \mathrm{Ra}=0.08097 \mathrm{ppm} \text { of } \mathrm{U} ; \\
& 1 \mathrm{~Bq} / \mathrm{kg} \text { of }{ }^{232} \mathrm{Th}=0.246305 \mathrm{ppm} \text { of } \mathrm{Th} ; \\
& 1 \mathrm{~Bq} / \mathrm{kg} \text { of }{ }^{40} \mathrm{~K}=0.003195 \% \text { of } \mathrm{K} .
\end{aligned}
$$

\section{Transfer factor and discrimination factor}

The ability of plants to uptake elements, expressed as the transfer factor, is similar for trees, grasses, and mosses (Zolotareva et al., 1983; Kabata-Pendias \& Pendias, 2001). The parameters needed for quantification of radionuclide transfer to biota are continually updated and are used for reconsideration of transfer factors recommended by the International Atomic Energy Agency (IAEA, 1994). Transfer factors (TF) from soil to moss were calculated as follows:

$$
T F=\frac{A_{\text {moss }}}{A_{\text {soil }}}
$$

Where $A_{\text {moss }}$ and $A_{\text {soil }}$ are concentrations of radionuclides in moss and soil, respectively.

It has been accepted that caesium enters the plant mainly via potassium transport system. ${ }^{40} \mathrm{~K}$ is a part of natural potassium which is the most abundant essential element in soil and plants. Since caesium and potassium belong to the same group of the periodic table and have similar chemical properties, mosses can discriminate between ${ }^{40} \mathrm{~K}$ and ${ }^{137} \mathrm{Cs}$ in the process of uptake of these radionuclides. Discrimination factor $(D F)$ is defined as:

$$
D F=\frac{T F_{C s}}{T F_{K}}
$$

where $T F_{C s}$ and $T F_{K}$ are transfer factors of ${ }^{137} \mathrm{Cs}$ and ${ }^{40} \mathrm{~K}$, respectively. DF value less than unity means that ${ }^{40} \mathrm{~K}$ is more efficiently absorbed by the plant than ${ }^{137}$ Cs (Zhu \& Smolders, 2000).

\section{RESULTS AND DISCUSSION}

Elemental concentrations of ${ }^{226} \mathrm{Ra},{ }^{232} \mathrm{Th}$ and ${ }^{40} \mathrm{~K}$ in soil and moss samples were calculated and presented in Table 2. Mean values of elemental concentrations are in good agreement with results reported for surface soils in Serbia (Dragović et al., 2014). The values of elemental concentration in moss are lower than in soil, which is expected, since the main source of primordial radionuclides is soil. The mean values of ${ }^{232} \mathrm{Th}$ elemental concentration for all the soil and moss samples were higher than for ${ }^{226} \mathrm{Ra} .{ }^{226} \mathrm{Ra}$ easily enters plants from soil and due to chemical activity it behaves similarly to calcium in an organism (Čučulović, 2016). ${ }^{226} \mathrm{Ra}$ elemental concentrations in mosses is related to direct deposition of ${ }^{222} \mathrm{Rn}$ progenies attached to the dust particles, which are accumulated by mosses from soil resuspension, through dry and/or wet atmospheric deposition of aerosols (Kiliç et al., 2019). Due to originally present potassium in the moss tissue, and ongoing physicochemical processes uptake pathways of ${ }^{40} \mathrm{~K}$ might be complex. Only sample S5 has higher percentage of ${ }^{40} \mathrm{~K}$ in moss than in soil.

Table 2. Elemental concentrations of radionuclides in soil and moss and descriptive statistics.

\begin{tabular}{|c|c|c|c|c|c|c|}
\hline \multirow{2}{*}{ Sample } & \multicolumn{2}{|c|}{$\begin{array}{c}{ }^{226} \mathrm{Ra} \\
(\mathrm{ppm})\end{array}$} & \multicolumn{2}{c|}{$\begin{array}{c}{ }^{232} \mathrm{Th} \\
(\mathrm{ppm})\end{array}$} & \multicolumn{2}{c|}{$\begin{array}{c}{ }^{40} \mathrm{~K} \\
(\%)\end{array}$} \\
\cline { 2 - 7 } & soil & moss & soil & moss & soil & moss \\
\hline S1 & 9.59 & 1.06 & 35.32 & 6.67 & 3.95 & 0.54 \\
\hline S2 & 1.17 & 0.15 & 3.65 & 0.84 & 0.51 & 0.38 \\
\hline S3 & 3.00 & 0.53 & 16.03 & 2.49 & 3.61 & 0.75 \\
\hline S4 & 2.28 & 0.15 & 12.22 & 1.11 & 1.44 & 0.36 \\
\hline S5 & 0.15 & $<$ MDA $^{*}$ & 0.39 & $<$ MDA $^{*}$ & 0.07 & 0.25 \\
\hline S6 & 1.40 & 0.08 & 5.49 & 0.20 & 0.51 & 0.38 \\
\hline S7 & 1.45 & 0.40 & 4.68 & 1.55 & 0.68 & 0.66 \\
\hline S8 & 2.74 & 0.23 & 11.58 & 1.08 & 1.89 & 0.51 \\
\hline S9 & 2.53 & 0.22 & 9.68 & 0.39 & 1.16 & 0.38 \\
\hline S10 & 1.68 & 0.09 & 7.86 & 0.71 & 0.77 & 0.34 \\
\hline S11 & 3.29 & 0.15 & 16.21 & 0.57 & 3.30 & 0.43 \\
\hline S12 & 2.84 & 0.29 & 13.50 & 1.50 & 2.43 & 0.48 \\
\hline Min & 0.15 & $<$ MDA* & 0.39 & $<$ MDA* & 0.07 & 0.25 \\
\hline Max & 9.59 & 1.06 & 35.32 & 6.67 & 3.95 & 0.66 \\
\hline Mean & 2.68 & 0.30 & 11.38 & 1.56 & 1.69 & 0.45 \\
\hline Median & 2.04 & 0.22 & 10.63 & 1.08 & 1.30 & 0.40 \\
\hline SD & 2.36 & 0.28 & 9.04 & 1.81 & 1.33 & 0.14 \\
\hline Skewness & 2.54 & 2.17 & 1.71 & 2.63 & 0.62 & 0.91 \\
\hline MDA*- 0.05 for ${ }^{226}$ Ra; 0.17 for ${ }^{232}$ Th & & \\
\hline
\end{tabular}

Figure 2 presents concentration of ${ }^{137} \mathrm{Cs}$ in soil and moss samples; the highest concentration in soil was noted in duff/mull soil (S5). Values of ${ }^{137} \mathrm{Cs}$ concentration in soil were higher than concentration in moss in six samples. Since ${ }^{137} \mathrm{Cs}$ is present more 
than thirty years in environment mainly from atmospheric Chernobyl's fallout, this is expectable. At the other side, the reasons of higher ${ }^{137} \mathrm{Cs}$ concentrations in moss than in soil samples could be related with altitude and pine forest. It could be considered in terms of features of localities: this occurred in coniferous forests (mosses in pine and spruce forests more readily uptake radionuclides than oak forests), and it could be related with acidic conifer needles, its retaining the soil moisture and making different substrate. Džoljić et al. (2017) reported very low $\mathrm{TF}_{\mathrm{Cs}}$ for spruce needles (range from not detected to 0.02 ), which could confirm washing out effect and deposition in substrate by precipitation.

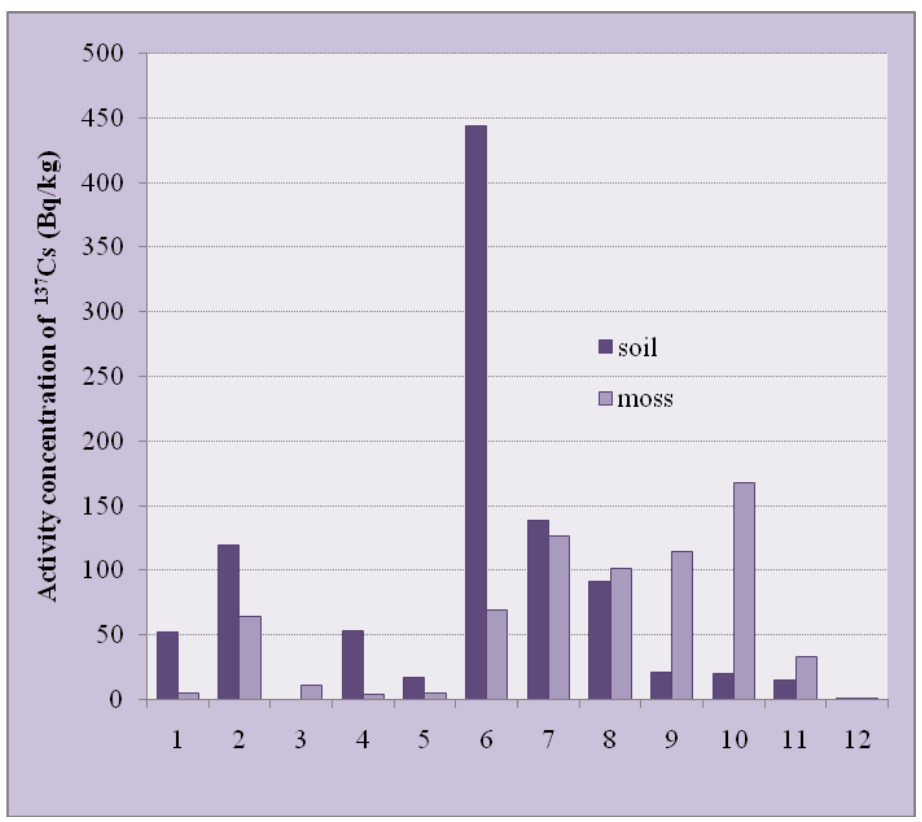

Figure2. Concentrations of ${ }^{137} \mathrm{Cs}$ in soil and moss samples.

The most important way of ${ }^{137} \mathrm{Cs}$ deposition in moss tissue is possibility that ${ }^{137} \mathrm{Cs}$ remains on the surface, which influences soil resuspension and transport to mosses (Ioannidou \& Papastefanou, 2006, Krmar et al., 2018); also, ${ }^{137} \mathrm{Cs}$ can be transported during growing period from older sections to newer sections of moss tissue (Krmar et al., 2018). Furthermore, physiological and morphological features of the same moss species may vary among localities; it includes different growing ages of moss tissue, different dynamic processes of biosorption by different sections of mosses) and hence, the accumulation of atmospheric fallout may differ (Kiliç et al., 2019). In addition, variability of radionuclide activities might be attributed to local climatic conditions (amount of rainfall, humidity and wind direction). The results indicate that these moss species absorb water and nutrients as well as other trace elements primarily through wet and dry deposition rather than from soil.

Transfer factors of ${ }^{226} \mathrm{Ra},{ }^{232} \mathrm{Th},{ }^{40} \mathrm{~K}$ and ${ }^{137} \mathrm{Cs}$ were calculated and presented in Table 3. TF for available data was in the range of $0.04-0.28$ for ${ }^{226} \mathrm{Ra}, 0.03-0.33$ for ${ }^{232} \mathrm{Th}$ and 0.13 3.63 for ${ }^{40} \mathrm{~K}$. A similar range for $\mathrm{TF}_{\mathrm{Ra}}(0.05-0.57)$ and $\mathrm{TF}_{\mathrm{Th}}$
(0.06-0.48) was obtained by Dragović et al. (2010) in the region of Zlatibor Mt. Moss capacity for absorption and retention of ${ }^{226} \mathrm{Ra}$ is much higher than in vascular plants (Tsikritzis et al., 2003). The $\mathrm{TF}_{K}$ is found to be more than unity for samples S5. With this exception, the values of $\mathrm{TF}_{\mathrm{K}}$ mainly fall into the range of results obtained from the Zlatibor mountain area, 0.15-0.96 (Dragović, 2010) and non-urban area in Southern Serbia, 0.190.90 (Popović, 2008). A range of soil-to-moss transfer factors of natural radionuclides ${ }^{226} \mathrm{Ra}$ and ${ }^{232} \mathrm{Th}$ can be explained by similar geochemical behavior which influences radionuclide distribution based on the topography and environmental processes such as weathering. Some researchers confirmed the existence of a synergistic and antagonistic relationship between individual elements (Kabata-Pendias \& Pendias, 2001).

Table 3. Transfer factors and discrimination factors.

\begin{tabular}{|c|c|c|c|c|c|}
\hline Sample & $\mathrm{TF}_{\mathrm{Ra}}$ & $\mathrm{TF}_{\mathrm{Th}}$ & $\mathrm{TF}_{\mathrm{K}}$ & $\mathrm{TF}_{\mathrm{Cs}}$ & $\mathrm{DF}$ \\
\hline $\mathrm{S} 1$ & 0.11 & 0.19 & 0.14 & 0.10 & 0.73 \\
\hline S2 & 0.13 & 0.23 & 0.74 & 0.53 & 0.72 \\
\hline S3 & 0.18 & 0.16 & 0.21 & - & - \\
\hline S4 & 0.07 & 0.09 & 0.25 & 0.09 & 0.34 \\
\hline S5 & - & - & 3.63 & 0.30 & 0.08 \\
\hline S6 & 0.06 & 0.04 & 0.74 & 0.16 & 0.21 \\
\hline S7 & 0.28 & 0.33 & 0.96 & 0.91 & 0.95 \\
\hline S8 & 0.09 & 0.09 & 0.27 & 1.11 & 4.14 \\
\hline S9 & 0.09 & 0.04 & 0.32 & 5.58 & 17.22 \\
\hline S10 & 0.05 & 0.09 & 0.44 & 8.50 & 19.39 \\
\hline S11 & 0.04 & 0.03 & 0.13 & 2.28 & 17.72 \\
\hline S12 & 0.10 & 0.11 & 0.20 & 1.22 & 6.21 \\
\hline
\end{tabular}

On the other hand transfer factors are spanning from 0.028.50 for ${ }^{137} \mathrm{Cs}$ (for available data). The values of $\mathrm{TF}_{\mathrm{Cs}}$ are lower than those reported by Dragović et al. (2010) for Zlatibor Mt. (1.01-13.1). The $\mathrm{TF}_{\mathrm{Cs}}$ are found to be more than unity for five of eight locations in Zubin Potok which could be attributed to mainly hilly terrain and higher precipitation rate. Some authors reported that the average transfer factor for ${ }^{137} \mathrm{Cs}$ in Hypnum cupressiforme was up to two-fold higher than for other moss species (Dragović et al., 2010).

The DF ranges from 0.08 to 19.39 for sampling locations (Table 3 ). For certain location (mosses in coniferous and mixed forests), DF is found to be more than unity which indicated that ${ }^{137} \mathrm{Cs}$ uptake by moss tissue is more readily than ${ }^{40} \mathrm{~K}$. Also, some authors report that certain synergistic effects have been observed for antagonist pairs of elements, which largely depend on the corresponding reaction of the plant species (Kabata-Pendias \& Pendias, 2001).

\section{CONCLUSION}

The mean values of ${ }^{226} \mathrm{Ra},{ }^{232} \mathrm{Th}$ and ${ }^{40} \mathrm{~K}$ elemental concentration and $137 \mathrm{Cs}$ activity concentrations measured in soil 
samples were comparable to the worldwide averages. Elemental concentrations in soil samples were in the range of $0.15-9.59$ ppm for ${ }^{226} \mathrm{Ra}, 0.39-35.32 \mathrm{ppm}$ for ${ }^{232} \mathrm{Th}$, and $0.07-3.95 \%$ for ${ }^{40} \mathrm{~K}$. Mean elemental concentration of ${ }^{232} \mathrm{Th}$ in soil and moss samples was higher than ${ }^{226} \mathrm{Ra}$. Wide ranges of values were observed; the values of natural radionuclides in moss are lower than in soil, since the main source of primordial radionuclides is soil. However, concentration of artificial ${ }^{137} \mathrm{Cs}$ does not show such a trend; it was higher in half of soil samples. ${ }^{137} \mathrm{Cs}$ activity concentrations in soil samples are spanning from 0.39-443.4 $\mathrm{Bq} / \mathrm{kg}$, while activity of this isotope in moss samples ranged from 1-168.1 Bq/kg. The variability of radionuclide activities might be attributed to local climatic conditions (amount of rainfall, humidity and wind direction). The results indicate that these moss species absorb water and nutrients as well as other trace elements primarily through wet and dry deposition rather than from soil. It was concluded that this occurred mainly in broad leaved, deciduous forest, while concentration of $\mathrm{Cs}$ in another six samples (coniferous and mixed forests) is higher in moss samples than in soil. Transfer factors of ${ }^{226} \mathrm{Ra},{ }^{232} \mathrm{Th}$, and ${ }^{40} \mathrm{~K}$ were in the range of $0.04-0.28,0.03-0.33$ and $0.13-3.63$, respectively. A range of soil-to-moss transfer factors of natural radionuclides ${ }^{226} \mathrm{Ra}$ and ${ }^{232} \mathrm{Th}$ can be explained by similar geochemical behavior which influences radionuclide distribution based on the topography and environmental processes such as weathering. The $\mathrm{TF}_{\mathrm{Cs}}$ are found to be more than unity for five of eight locations in Zubin Potok which could be attributed to mainly hilly terrain and higher precipitation rate. DF is found to be more than unity which indicated that ${ }^{137} \mathrm{Cs}$ uptake by moss tissue is more readily than ${ }^{40} \mathrm{~K}$.

Based on results and discussion it can be pointed out that significant radiological contamination in terms of natural and artificial radionuclides in area of Kosovska Mitrovica and Zubin Potok municipalities does not exist.

\section{ACKNOWLEGMENTS}

The present work was supported by Serbian Ministry of Education, Science and Technological Development (Agreement No. 451-03-68/2020-14/200378) and supported by the Faculty of Natural Sciences and Mathematics, University of Priština, Kosovska Mitrovica within the project No. IJ01-17.

\section{REFERENCES}

Aceto, M., Abollino, O., Conca, R., Malandrino, M., Mentasti, E., \& Sarzanini, C. 2003. The use of mosses as environmental metal pollution indicators. Chemosphere 50, pp. 333-342. DOI;10.1016/S0045-6535(02)00533-7

Hydrometeorological Yearbook of Kosovo, 2017-2018. https://www.ammk-rks.net/?page=2,25

Čučulović A., Čučulović R., Sabovljević M., Radenković M.B., \& Veselinović D. 2016. Natural radionuclide uptake by mosses in eastern Serbia in 2008-2013. Arhiv za Higijenu
Rada i Toksikologiju 67, pp. 31-37. DOI: 10.1515/aiht-201667-2695

Čučulović, A., Popović, D., Čučulović, R., \& Ajtić, J. 2012. Natural radionuclides and ${ }^{137} \mathrm{Cs}$ in moss and lichen in Eastern Serbia. Nuclear Technology and Radiation Protection 27, pp. 44-51. DOI: 10.2298/NTRP1201044Č

Dimitrijević, M. D. 1997. Geology of Yugoslavia. Geol. Inst. GEMINI, Belgrade.

Dolegowska, S. \& Migaszewski Z.M. 2019. Biomonitoring with mosses: Uncertainties related to sampling period, intra-site variability, and cleaning treatments. Ecological Indicators 101, pp. 296-302. DOI: 10.1016/j.ecolind.2019.01.033

Dragović, S., Janković Lj., Onjia A., \& Bačić G. 2006. Distribution of primordial radionuclides in surface soils from Serbia and Montenegro. Radiation Measurements 41, pp. 611 - 616. DOI:10.1016/j.radmeas.2006.03.007

Dragović, S., Janković-Mandić, Lj., Dragović, R., Đorđević, M., Đokić, M., \& Kovačević, J. 2014. Lithogenic radionuclides in surface soils of Serbia: Spatial distribution and relation to geological formations. Journal of Geochemical Exploration 142, pp. 4-10.DOI: 10.1016/j.gexplo.2013.07.015

Dragović, S., \& Mihailović, N. 2009. Analysis of mosses and topsoils for detecting sources of heavy metal pollution: multivariate and enrichment factor analysis. Environmental Monitoring and Assessment. 157, pp. 383-390. DOI: 10.1007/s10661-008-0543-8

Dragović, S., Mihailović N., \& Gajić B. 2010. Quantification of transfer of ${ }^{238} \mathrm{U},{ }^{226} \mathrm{Ra},{ }^{232} \mathrm{Th},{ }^{40} \mathrm{~K}$ and ${ }^{137} \mathrm{Cs}$ in mosses of a semi-natural ecosystem. Journal of Environmental Radioactivity 101, pp. 159-164. DOI: 10.1016/j.jenvrad.2009.09.011

Džoljić, A. J., Stevović, M. S., Todorović, J. D., Polavder, M. S., Rajačić, M. M., \& Krneta Nikolić, N. J. 2017. Natural and artificial radioactivity in some protected areas of south east Europe. Nuclear Technology and Radiation Protection, 32, pp. 334-341. DOI: 10.2298/NTRP1704334D

Fernandez, J. A., \& Carballeira, A. 2000. Evaluation of contamination by different elements in terrestrial mosses. Archives of Environmental Contamination and Toxicology 40, pp. 461-468. DOI:10.1007/s002440010198

Frahm, J. P. 2009. A preliminary study of the infraspecific taxa of Hypnum cupressiforme in Europe. Archive for Biology 40, pp. 1-10. ISSN 0945-3466.

Grdović, S., Vitorović, G., Mitrović, B., Andrić, V., Petrujkić, B., \& Obradović, M. 2010. Natural and anthropogenic radioactivity of feedstuffs, mosses and soil in the Belgrade environment, Serbia. Archives of Biological Sciences 62 (2), pp. 301-307. DOI:10.2298/ABS1002301G

IAEA, 1994. Handbook of Parameter Values for the Prediction of Radionuclide Transfer in Temperate Environments. Technical Report Series No. 364. IAEA, Vienna.

Ioannidou, A., \& Papastefanou, C. 2006. Precipitation scavenging of $7 \mathrm{Be}$ and $137 \mathrm{Cs}$ radionuclides in air. Journal of Environmental Radioactivity 85, pp.121-136. DOI: 10.1016/j.jenvrad.2005.06.005

Ivanić M., Fiket Ž., Medunić G., Furdek Turk M., Marović G., Senčar J., \& Kniewald G. 2019. Multi-element composition of soil, mosses and mushrooms and assessment of natural and artificial radioactivity of a pristine temperate rainforest system (Slavonia, Croatia). Chemosphere 215, pp. 668-677. 
Ivanović, R., Valjarević, A., Vukoičić, D., \& Radovanović, D. 2016. Climatic regions of Kosovo and Metohija. University Thought Publication in Natural Sciences, 6(1), pp. 49-54.

Kabata-Pendias, A., \& Pendias, H. 2001. Trace elements in soils and plants $\left(3^{\text {rd }}\right.$ ed.). New York, London, Taylor and Francis Group Boca Ration: CRC Press

Kiliç, Ö., Belivermiş, M., Sıkdokur, E., Sezer, N., Erentürk, S.A., Haciyakupoglu, S., Madadzada, A., \& Frontasyeva, M. 2019. Assessment of ${ }^{210} \mathrm{Po}$ and ${ }^{210} \mathrm{~Pb}$ by moss biomonitoring technique in Thrace region of Turkey. Journal of Radioanalytical and Nuclear Chemistry 322, pp. 699-706. DOI: 10.1007/s10967-019-06721-4

Krmar, M., Radnović, D., Hansman, J., Mesaroš, M., Betsou, C., Jakšić, T., \& Vasić, P. 2018. Spatial distribution of ${ }^{7} \mathrm{Be}$ and ${ }^{137} \mathrm{Cs}$ measured with the use of biomonitors. Journal of Radioanalytical and Nuclear Chemistry 318, pp. 1845-1854. DOI: 10.1007/s10967-018-6121-9

Mitrović, B., Ajtić, J., Lazić, M., Andrić, V., Krstić, N., Vranješ, B., \& Vićentijević, M. 2016. Natural and anthropogenic radioactivity in the environment of Kopaonik mountain, Serbia. Environmental Pollution 215, pp. 273-279. DOI:10.1016/j.envpol.2016.05.031

Mitrović B., Vitorović G., Vitorović D., Pantelić G., Adamović I. 2009. Natural and anthropogenic radioactivity in the environment of mountain region of Serbia, Journal of Environmental Monitoring 11, pp. 383-388. DOI: $10.1039 / \mathrm{b} 813102 \mathrm{c}$

Popović, D., Todorović, D., Frontasyeva, M., Ajtić, J., Tasić, M., \& Rajšić, S. 2008. Radionuclides and heavy metals in Borovac, Southern Serbia. Environmental Science \&
Pollution Research 15, pp. 509-520. DOI 10.1007/s11356008-0003-6

Tsikritzis, L. I., Ganatsios, S. S., Duliu, O. G., \& Sawidis, T. D. 2003. Natural and artificial radionuclides distribution in some lichens, mosses, and trees in the vicinity of lignite power plants from West Macedonia, Greece. Journal of trace and microprobe techniques 21, pp. 543-554. DOI:10.1081/TMA120023070

Tzortzis, M., \& Tsertos, H. 2004. Determination of thorium, uranium and potassium elemental concentrations in surface soils in Cyprus. Journal of Environmental Radioactivity 77, pp. 325-338. DOI: 10.1016/j.jenvrad.2004.03.014

UNSCEAR, 2008. Report to the General Assembly, Annex B: Exposure of the public and workers from various sources of radiation. United Nations, New York.

Zechmeister, H. G. 1995. Growth rates of five pleurocarpous moss species under various climatic conditions. Journal of Bryology 18, pp. 455-468. DOI:10.1179/jbr.1995.18.3.455

Zhu, Y-G., \& Smolders E. 2000. Plant uptake of radiocaesium: a review of mechanisms, regulation and application. Journal of Experimental Botany 51, pp.1635-1645. DOI:10.1093/jexbot/51.351.1635

Zolotareva, B. N., Skripnichenko, I. I., Ableev, M. Kh., Ostroumov, V. E., Geletyuk, N. I., Shitova (Koroleva), E. G., \& Zablotskaya, L. V. 1983. Heavy metals in biogeocenoses of the Prioksko-Terrasny Biosphere Reserve, in Ecological Monitoring of the Prioksko-Terrasny Biosphere Reserve 56 (in Russian). 